\title{
MEANING OF CAROK FOR MADURANESE (INDONESIAN TRIBE): A CASE STUDY IN SAMPANG, MADURA ISLAND
}

\author{
Rahmi Purwati Ayu*, Cahyaningrum Dinis, Putri Kholifatul Wanda, Listiyawaty Yuyun \\ Magister Program of Human Resource Development, University of Airlangga, Indonesia \\ *E-mail: ayurahmi93@gmail.com
}

\begin{abstract}
Carok is an expression of Madura's men to defend self-esteem when harassed by others men and symbol of virility even end by dying one or both. This action closely related to the cultural values that used as guidelines for the Maduranese behavior. Yet Carok cannot be equated with cases of criminal murder in general, it can be done with deliberation on both side. The purpose of this study is to know the history of Carok and how people interpret the tradition of Carok in resolving conflicts in society. The method used in this research is qualitative descriptive. Currently, Carok is interpreted as a mechanism of conflict resolution to uphold individual or family self-esteem; instead the closer family from dying fighter such as son, father and brother could fight back the murderer. It is because Maduranese believes that their self-esteem is more valuable than life. The references to the carok are limited; the writings of ancient times vary in depicting the history of Carok itself. The informants stated that Carok does not happen as often as in the past because young generation today has better education.
\end{abstract}

\section{KEY WORDS}

Carok, Maduranese, culture, crime, defense of self-esteem.

Society and custom are two things that cannot be separated. Interestingly, each community group has different customs so that it becomes the hallmark of the group. In Indonesia for example, The Madura tribe that has a distinctive characteristic with dialect, appearance, work, clothes and so on. The Maduranese community in Indonesia is known as a society that has strong character, unique, stereotypical, stigmatic and distinctive culture. Those typically refer to Maduranese entity has a cultural specialty unlike the ethnography of other communities in Indonesia (Alwi, 2001). The Maduranese cultural differences or uniqueness often is led other ethnic groups Maduranese seeing this as absurd behaviour. For example, Maduranese are known as cranky, and then choose the alternative solution to their irritation through physical violence, usually a Carok (Taufiqurrahman, ND).

Carok is an action or assassination attempt using a sharp weapon, generally sickle among two men who one of them considered to harass self-esteem. The motive or background of the Carok event is mostly due to problems of disruption wife or fiancee, misunderstanding, seizure of land or inheritance, bad debts and other unknown reasons. Carok in the phrase Madura likened to "Lebbi Bagus Pote Tollang atembang Pote Mata" which means (Better to die, than live to bear the shame) (Wiyata, 2002). Carok is at the crossroads of tradition in society and Carok as a form of violent crime that is very disturbing to society as well as actions that are not justified by the State and religion as classified to the act of vigilante.

The tradition of Carok by people outside Maduranese is understood as a peculiarity of customs and also legal violations that are legalized by society. So that Maduranese people in some areas imaged as a impolite, rude, violent, and cranky. However, not infrequently all people label that, that images will be gone after they make real communication with Maduranese. The background makes author interested to study Carok in Maduranese perspective by focusing on the study of how the history of Carok, and how Maduranese people interpret the Carok currently because of the difference Carok meaning today from the past and how people suggestion to minimize Carok Case. So this study is expected to give a 
complete picture of the Carok that is understood by Madura community so that all people and reader can open their minds if Maduranese has a good attitude and characteristic.

\section{LITERATURE REVIEW}

The most powerful and prominent labelling of Maduranese ethnic group is physical violence that leads to fighting armed with sickle popularly known as Carok. Carok tradition in Maduranese community is a manifestation of the desire to defend self-esteem and family honour. The use of Carok tradition is expected to rehabilitate the impact of self-esteem harassment, otherwise, the family honor in the community's view has no value (Safioedin, 1979).

All of Carok's cases are initiated by specific conflict such as the occurrence of disturbing a wife by other man, fraud accusations, seizure of inheritance, vengeance), all of them are referring to the same thing that is harassment of self-esteem (dignity). To recover their harassed self-esteem, they do Carok, which is always supported by social environment. The man who success loses their enemies shows a feeling of relief, satisfaction and pride (Wiyata, 2002). Wiyata continues, the occurrence of Carok is closely related to a lot of conditions, such as, first, the socio-cultural conditions that bring a hoodlum into social status at the upper level in the social structure of Maduranese community. Second, the condition of some judicial officers' behaviour that do not consistently apply and enact laws in accordance with legislation, so that the legal judgments taken are very unsatisfying the sense of justice for local communities. Third, until now, socio-cultural conditions in Madura have not known any institution that serves and acts as a deterrent or antidote to the occurrence of Carok (Wiyata, 2002). Ignoring the facts, Maduranese seem to have two opposing personalities. They do not hesitate to easily shed blood if their self-esteem and honor are disturbed. The stubborn is reflected in Carok. On the contrary, they have the tenderness of the yarn-like nature which is reflected in Maduranese attitude of life which assumes that all people are brothers (Abdurrahman, 1979).

The study of Carok has been done by Hidayat with the title of "Philosophy of Carok Study on The Nature of Appreciation and Disharmony in Carok Tradition". This research is a literature research. Research shows, the nature of Carok tradition in terms of ontology, the cause of Carok is based on self-esteem and socio-cultural factors. Epistemologically, Carok is an instrument to maintain self-esteem must be done in order for an individual to be respected and acknowledged as a worthy party. Axiologically, self-esteem has a spiritual and socio-cultural value containing an ethical value (Hidayat and Lasiyo, ND).

\section{METHODS OF RESEARCH}

This researcher uses the qualitative methodology, collecting data from informants on descriptive data in the form of written or oral words of people and behaviour that can be observed thoroughly about the form, function and meaning of the expression (Robert and Taylor, 1975). This research chose two villages in asub-district in Sampang. Those are Pekalongan Village, Sampang Distric and Temoran Village, Omben District, Sampang regency by consideration of the perspective diversity of people who live in the main city of Sampang and people in the suburb. Types of data obtained from this study are primary data obtained through observation and interviews with the people of Sampang and secondary data from mass media and other supporting literature such as books or scientific journals.

Determination of informant used in this research is purposive and developed with the snow ball. The selected Key informants were local village apparatus: Mr Nurcholis as a staff of Pekalongan Village Office and Mrs Wayas who was appointed directly by Temoran village head because at the time of data collection the village head was out of town. Then the deeper information is searched to other informants in the village of Pekalongan, they are Umi Siti, Mr Jamaludin, Ustad Zaini, Mrs Lilik, Nur Cholis and informants from Temoran Village, Wayas, AR, Umar Neto, Sukron, Ma'mun, Ustad Rozaq. The secondary data is obtained from previous books and research. 


\section{RESULTS AND DISCUSSION}

History of Carok. Based on the description of De Jonge the emergence of acts of violence in the life of Maduranese is caused by two important things. The first was the government at that time did not pay attention to the Maduranese and the second is as a consequence of the first cause, the community became distrustful to the government, thus any problems or conflicts were resolved in their own way in violence regardless of the rules. The solution intended is Carok. In 1700s VOC began to control Madura. At that time there were three kingdoms politically given the right and authority by VOC to take care of its own government. Thus the king of Madura freely determined forced labour, withdrawing income tax or money tax. The longer the community felt very miserable and the condition of land that barely could support the community. The belief in the law was gone. Criminal acts were everywhere and people sought solutions in various ways of self-help. Citing a report of a government official, Brest Ban Kempen who became an assistant resident in Bangkalan in 1847-1851, said the court was not working and the bodies of the victims were dumped in the town square and virtually no judicial proceedings. Even if there was a judicial process, suspects and witnesses were held in prison for months without trial. In the 19th century, the colonial government forbade to bring a sharp weapon because at that time a sharp weapon as if to hoard Madura Strait. But the result of this policy is nil because the root of the problem was the feudalistic government elite. According to De Jonge (Wiyata, 2002), the situation in Madura began to change direct government system was applied.

Refer to the search of articles written by Maduranese in electronic media, Carok history emerged among the Maduranese since the era of Dutch colonialism in the 18th century. Carok is a knight symbol in the fight for self-esteem (honoru). Clurit began to appear in the age of Sakera legend. Clurit was used by Sakera as a symbol of resistance of commoners against Dutch colonizers. Instead for Dutch, Clurit was symbolized as a weapon of criminals. Those Dutch efforts were apparently managed to penetrate some Maduranese and become the philosophy of their life. When there are problems, infidelity, seizure of land, and so on, Carok is always the solution for upholding self-esteem. Similarly, when doing the crime, also using a sickle. Such conditions eventually, drive people outside Madura to label Maduranese like to perform Carok and being rough. Meanwhile, not all of Maduranese live that way. Maduranese have a subtle attitude, know good manners, do not like to quarrel. Carok behaviour is the descendant of the ancient people who aimed against Dutch colonizers. After so many years of Dutch colonialists left the island of Madura, Carok culture and using as sickle to finish off his opponent still exist, whether in Bangkalan, Sampang, and Pamekasan. They think that culture is the creation of his ancestors, not aware that it is the results of the Dutch colonial falsity.

Characterizing Sakera with a soul of a knight eradicate Dutch colonialism was also expressed by Mr Rozak. It came from an old Dutch story, Sakera who was born in Sampang, Madura. Sakera eradicated Dutch without fear with his organization (Interviewed with a religious figure; Mr Rozak). Another story that develops about the Sakera figure that a brave knight against the bourgeoisie. He took the wealth of rich people to be distributed to poor people in Sampang. The weapon that used is clurit. However, as time goes by, Carok is misunderstood, Carok becomes a symbol of courage to defend one's personal self-esteem (Interviewed with Woman Figure; Mrs Wayas). Based on the different early history of Carok it can be concluded that the key problem comes from weak law enforcement by the authorities and also the government system that is not on its people's side. Consequently, people prefer to create legal tools that they consider to provide a deterrent to the perpetrators of crime effectively.

Understanding of Carok by Maduranese. Carok is an institutionalization of violence that historically has been practiced by several Maduranese since several centuries ago. In addition, Carok also starts from the weakness of state authority since before and after independence to control the source of violence and the inability to provide justice to the community. This results, Carok performers are less able to express the language, thus 
putting forward the aggressive physical behaviour in eliminating the lives of people who are considered harassing self-esteem (Wiyata, 2002).

According to field research, Mr Jami clarifies Carok is as an instrument to vent the resentment through assassination attempts. This fight is only meant for the act of fighting between men only because the action of fight between men and women is considered not a gentleman. This fight is a form of social control so people can control their behaviuor, especially in respecting the rights of others, because people still do not fully believe in the existing legal institutions. Because Carok has existed before legal institutions legalized by the government. Carok is generally done by a man when he knows his wife is harassed by another man because the wife must be kept well by the husband (Interviewed with Public Figure, Mr Jami). The people themselves, even those who are aware of the legal system, do not have the courage to interfere in violation of the law between the two parties in conflict. This is because the unwritten rules that are already believed and agreed by Maduranese, that between two parties in conflict, the other party cannot interfere (Interview with Woman Figure, Mrs Wayas). The unwritten rules still exist due to some people perspective about law taking sides to a person who has the good financial ability then they can buy and set the case lighter. So when a conflict occurs, the solution that is considered the fairest is to apply vigilante (Interview with hoodlum; AR).

On the other hand, regarding to Carok as a symbol of men's courage, nowadays the meaning of Carok as a courageous act is rarely encountered. Carok is often engineered by the perpetrators. Carok has now been organized in such a way that the perpetrator has prepared how the legal method will be met. In the same way, a murder could use the role of an assassin or the murderer does not have to be jailed (Interview with Staff Administrative In Pakalongan Village; Mr Nurcholis). Along with the level of public participation in education in Sampang Regency added by development infrastructures in Madura Island, urban communities have started to leave Carok as an attempt to resolve the conflict (Interviewed with a Collegian, Ma'Mun). Contras, some marginalized society in suburbs still legalize Carok. Even, to protect themselves from attack unexpectedly, they always save a sickle behind their backs so they can fight back (interviewed with Religious Figure; Ahmad Zaini).

All findings conclude Carok as a mechanism for resolving conflicts especially when a Maduranese man feel his pride disturbed by the other man. The doers choose Carok because of the system of law cannot give them the consistent justice to poor people. Even, the aware people in law do not have a big bravery to make the fighter burying the hatchet. Majority cases happen in suburbs area with low quality of education.

Efforts to Minimize Carok. In accordance with the applicable law in Indonesia, as stipulated in Legal Criminal Code, Carok is categorized as murder (article 338 and 340) or persecution (article $351,353,354,355$ ) so that the perpetrator must be jailed for years or even sentenced death. However, the public assumption, the law does not go like that. Carok perpetrators serve only a minor punishment and their role as perpetrators can be replaced by other parties. The impact of this affection the people's scepticism in the legal institutions of the police and judicial institutions. Society understands the legal constraints on lower-class economic society. On the other hand, because Carok has become a habit, people already understand the rules of the game and choose not to intervene when Carok takes place. One of a way to reduce the case Carok by involving tradition leaders, religious leaders and even informal characterizations such as tojing or bajing (hoodlum in English) (Interview with Woman Figure, Mrs Wayas). For example, one of the religious leaders who is considered to be able to reconcile the two sides of the family is a Religious leader who comes from the district Omben, Sampang regency. He brought both sides who promised to make peace. The public believes that if the promise is violated then he will get injured (Interview with Staff Administrative in Pakalongan Village; Mr Nurcholis). The role of the two families is also one of the options to resolve Carok that runs through generations, meetings between two ancestors or people who are considered elder to end the dispute between the two families. So that there is no longer vengeance between both families (Interview with Woman Figure; Mrs Lilik). 
Another mechanism to minimize Carok is through education and religion. Carok occurs due to the lack of education and knowledge of whole Islamic religion, especially in the suburbs (Interview with religious Figure, Ahmad Zaini). In his book, Wiyata clarifies the lack of education as a factor that causes Maduranese to be provoked by the conflicts of every socio-economic problem affecting the region. Moreover, the social issues are offensive and involving self-esteem (Wiyata, 2002). This statement was supported by Mrs Wayas and Mr Umar Neto. Maduranese are poorly educated, it was rarely found Maduranese who was able to finish junior high school, high school, consequently, their thoughts are easily stuffed by something that is not good because their parents are not educated. In contrary, if parents are already educated, parents will lead the children not to choose Carok as a decision to end the self-esteem conflicts

Embedding a good education system towards the young generation is very important because education will make young people think about the consequences of crime, so Carok actions can be minimized. According to one of the community leaders we interviewed, the need for additional educational facilities or infrastructures and religious knowledge will be able to develop the human resources capacity of Maduranese so as to suppress potential of Carok or other potential crime (Interview with Public Figure, Mr Umar Neto). Besides, the importance of the village youth to maintain order, for example, one of the youth leaders mentioned the importance of conducting youth activities and discussion among youth so as to create harmony among youth in their area. It is also transferred to the younger generations in the village through discussion forums and they are as much as possible not to mention the word Carok in their discussion (Interview with Youth Figure; Sukron). In the contrary, one of hoodlum who is poorly educated has a different opinion. He believed no matter how high educated Maduranese could be, they would do Carok. In fact, he does not hesitate to tell his son to do Carokif the child's self-esteem is disturbed (Interview with Hoodlum; AR).

The statement of several informants above shows the public's critical attitude about the importance of facilities and infrastructure of good human resource development in society by the government. The initiatives to stop Carok are also done by parents by providing education and provision of good religion to their children and the existence of an active youth organization to minimize the spread of the tradition of conflict resolution through Carok by not socializing or disseminating all matters related to Carok. This study supports the study compiled by Hidayat, that Carok is an instrument to maintain self-esteem to be appreciated and acknowledged by others. Although in Sampang region there are already legal and religious institutions, most people, especially in the suburbs, they continue to understand Carok as a solute conflict resolution. In contrast to the prismatic worldviews in Sampang region who are more open to new things, they tend to criticize Carok as an attempt to defend self-esteem.

\section{CONCLUSION}

Madura tribe, one of the biggest tribe in Indonesia, has a distinctive character with dialect, appearance, work, clothing and so forth. Just same as other ethnic groups with distinctive cultures and customs, Maduranese also has a mechanism for resolving conflicts of self-esteem abuse between men and fights known as Carok. Carok is an institutionalization of violence that has historically been practised by some Maduranese people since several centuries ago. The history of Carok is defined by society in various ways. The red line from various sources of problems arises from the weakness of law enforcement by the governmental system that puts the people in a poor sphere. So the public would prefer to create a resolving conflict by their own that they deem effective to provide a deterrent to the person that started the conflict. Sampang people agree if Carok largely often starts from the interference of women who already have husbands by other men, then the husband feels harassed his self-esteem so to cure the heartache the husband must do duel with "Carok", the next cause is slander case, seizure Inheritance, accounts payable and revenge for the dying family member. Carok still occurs because some people still consider the weakness of law enforcement also the lack of public access to education in schools. So it is important for 
the government to reduce the number of Carok cases by providing good education in schools and religious education. As well as the importance of cooperation between governments, law enforcement with community leaders and religious leaders.

\section{REFERENCES}

1. Abdurrahman. (1979), "Problem of Carok in Madura, Madura III". Indonesia Ministry of Education and Culture, Jakarta.

2. Alwi, Hasan. (2001), "Indonesia Dictionary, Third Edition", Jakarta: Indonesia Ministry of Education and Culture and Balai Pustaka.

3. Asis Safioedin. (1979), "Carok Is Ordinary Murder Crime, Madura Research Seminar Paper In The Framework Of Indonesia-Netherlands Cooperation For The Development Of Indonesian Studies", Batu-Malang, 1979

4. Hidayat, A.R. and Lasiyo. (ND), "The Carok Philosophy of The Study of The Essence of Internalization of Harmony and Disharmony in the Carok Tradition", Gadjah Mada University.

5. Robert C, dan SJ. Taylor. (1975) "Introduction to Qualitative research Methods: A Phenomenological Approach to the Social Sciences, New York, John Willey \& Sons.

6. Taufiqurrahman. ND, "Madura Cultural Identity", Pamekasan: STAIN Pamekasan University, Unpublished Journal

7. Wiyata, Latief. (2002), "Carok Violent Conflict and Self-Maduranese Pride", Yogyakarta: LKiS. 